\section{Canadian 1ruth Commission Attempts to Overcome Guatemalan Refugees' Fear and Cynicism}

\section{Judith Pyke}

A Truth Commission for the Canadian Guatemalan community finished taking the last of its testimonies from refugees in Ottawa, Montreal and Toronto, Canada on April 30, 1998. Altogether, the commission took 34 testimonies and documented 82 cases of human rights abuses in Guatemala. It was funded by Canada's Department of Foreign Affairs. The testimonies will be incorporated into a report being prepared by the year-long Truth Commission based in Guatemala, which will wrap up on July 31st, 1998.

Guatemala's thirty-five year civil war ended officially in December 1996, when government and warring guerrilla factions signed several peace accords. During the conflict, over 150,000 people died, 50,000 disappeared and thousands more were orphaned and widowed. One million people became refugees, out of a total population of 11 million.

"I think it's important from a Canadian perspective to recognize that we have people in our midst who are living with memories of these horrible situations" said Albert Koehl, a Canadian lawyer who helped initiate the Truth Commission in Canada, and who worked for the commission in Guatemala. However, Koehl acknowledges that many members of the Canadian Guatemalan refugee community, which he estimates at roughly 8,000 , found that "the process just hurts too much" and did not want to participate. Others remain unsure whether the commission will have an impact on the situation in Guatemala. Those who did participate hope that public articulation of human rights abuses in Guatemala will engender public recognition of war atrocities

Judith Pyke is a Toronto-based writer and media producer who has spent time in Central America.

and help Guatemalans and their CO\111try to begin to heal.

'This is good for future generations, and it's importantto record Guatemala's history," said Francisco Hernandez, who gave testimony atthetruthcommission's proceedings. He is "tired of the bad situation in Guatemala" and does not want the violence to repeat itself. Hernandez came to Canada as a refugee fourteen years ago, after he was threatened with kidnapping by the army. However, Hernandez, like many Guatemalans, is unsure whether a truth commission or the peace agreement will usher in a new era for Guatemala.

"Latin America has a history of sudden reversals and coups, and it would be negligent to say that there is a guarantee that things are going to keep moving in a positive direction, but that's the hope," said John Tyynella, who works for the United Nations in Guatemala. Tyynella stressed that public participation in processes like the Truth Commission and the implementation of the peace accords has to overcome a strong sense of "apathy, skepticism and a sense that there really is no way to participate in the government." Despite the fact that there are more sanctioned opportunities for discussion, Guatemala's culture of fear persists, perpetuated by continuing government corruption and fundamental economic needs throughout the country.

The brutal killing ofBishop Juan Jose Gerardi in April, after he published a report on human rights abuses in Guatemala, sent a strong message to the Guatemalan Canadian community. There is a sense that repression is starting again, said Hernandez. He, like many others, urges that continued international presence and attention is essential if Guatemala is to continue on its path to restoring a civil and just society. II

\section{REPORTS \\ - Somali Refugees in Toronto: A Profile \\ By Edward Opoku-Dapaah \\ ISBN 1-55014-278-x, 130 pp., \$12.95.}

This is the first comprehensive study of Somali refugees in Toronto. It examines the social, residential, and linguistic characteristic of Somalis, their participation in the local economy, and the activity of Somali community organizations. The report also contains valuable suggestions and recommendations concerning suitable and more efficient service delivery to this community.

- Cambodian Refugees in Ontario: An Evaluation of Resettlement and Adaptation

By Janet McLellan,

ISBN 1-55014-267-4, 142 pp., \$12.95.

This major study of Cambodian refugees in Ontario examines the effects of various forms of sponsorship on Cambodian resettlement. It also focuses and the linguistic, economic, educational, training and social dimensions of the whole process of adaptation. The delivery of services by governmental and NGO agencies as well as the effects of the past traumatic experiences of genocide and mass starvation on Cambodian refugees are fully discussed.

- Refugee Families and Children: A Directory for Service Providers in Metro Toronto

Compiled by

Dr. John Morris and Lydia Sawicki. ISBN 1-55014-285-2,39 pp., \$6.95.

This directory is designed for service providers who work with refugee families and children in Metro Toronto. Its aim is to improve service provision through networking and the sharing of training opportunities.

Availablefrom

Centre for Refugee Studies 
(. . .

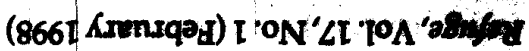

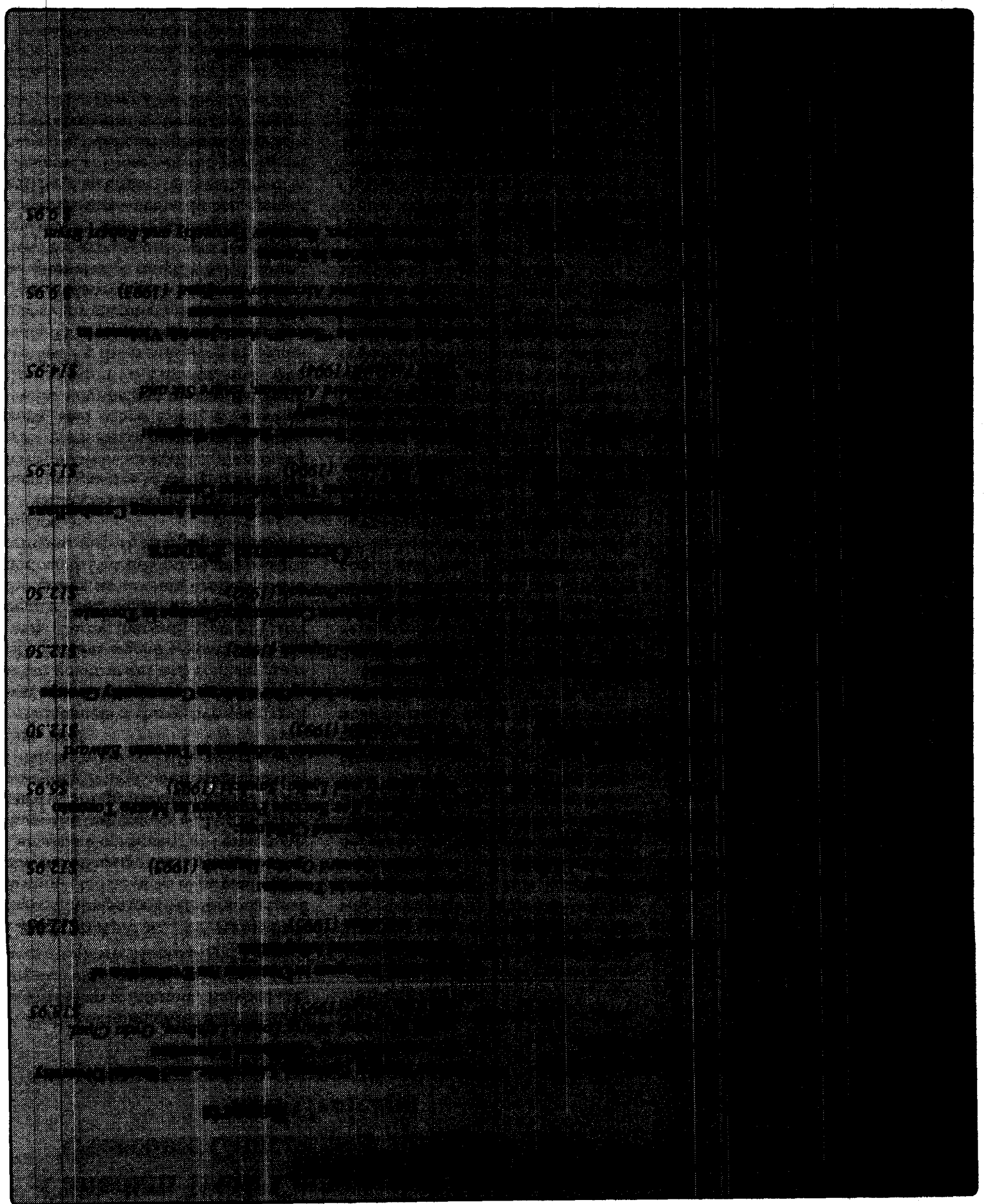

Judith Pyke, 1998. This open-access work is licensed under a Creative Commons Attribution-NonCommercial 4.0 International License, which permits use, reproduction and distribution in any medium for non-commercial purposes, provided the original author(s) are credited and the original publication in Refuge: Canada's Journal on Refugees is cited. 


\section{Legitimate and Illegitimate Discrimination: New \\ Issues in Migration}

\section{Edited by HowardAdelman}

ISBN 1-55014-23 .1995.

287 pp., indexed. $\$ 22.95$

Freedom of movement: If the members of a state are forced to flee, the legitimacy of that government is questionable. On the other hand, if members cannot or must leave, again the government is not democratically legitimate.

Immigration control: While limiting access and determining who mayor may not become members of a sovereign state remains a legitimate prerogative of the state, the criteria, rules and processes for doing so must be compatible with its character as a democratic state.

Legitimate and Illegitimate Discrimination: New Issues in Migration, edited by Professor Howard Adelman, deals with the question oflegitimacywith cases studies from the Developing World, Europe, Australia, the United States, and Canada.

CONTRIBUTORS:

Rainer Baub6ck, HowardAdelman, Gaim Kibreab, A. Essuman-Johnson, Grant M. Farr, Lawrence Lam, Oscar SchiappaPietra, Tomas Hammar, Frederic Tiberghien (in French), Lois Foster, and Arthur C. Helton

Available from

Centre for Refugee Studies

Tel.: (416) 736-5843

Fax: (416) 736-5837

Email: refuge@yorku.ca

\section{Back Issues of Refuge}

The following is a list of general and thematic issues of RefUge-Canada's periodical on refugees.

1. Environmental Refugees. Vol. 12, No.1. June 1992.

2. Discussion of Immigration BUt C-86. Vol. 12, No.2. July/(Aug.) 1992.

3. General Issue/Refugee Sponsot\$wp, Vol. 12, No.3. Sept. 1992.

4. Eastern European Refugees. Vol. 12. No.4. OCt. 1992.

5. The TrasedrofSomalia, Vol. 12. N().5. Npv./Dcc.I992

6. The Reviewof:Rejecccd Refugee Claims in Canada, VoL 12. No.6. Jan. 1993.

7. Russia and Central Eurasia. Vol. 12. No.7. February 1993.

8. Africa Issue: Repatriation, Vol. 12. No.8. March 1993.

9. General Issue/Globalization. Vol. 13. No. 1, April 1993.

10. Russia and Central Eurasia. Vol. 13, No.2. May 1993.

11. Special Issue on Sri Lanka. Vol. 13. No.3, June 1993.

12. Gender Issues al!d Refugee Law, Vol. 13. No.4, July/Aug. 1993

13. Southeast Asian Refugees. Vol. 13. No.5, Sept. 1993.

14. Mozambican Refugees. Vol. 13. No.6, OCtober 1993.

15. Russia and Central Eurasia. Vol. 13. No.7, Nov./Dee. 1993.

16. General I\$Sue/Sudan. Vol. 13. No.8. January 1994.

17. Integration of RdUgees-The Canadian Experience, Vol. 13, No.9. Feb. 1994

18. Refugees and Peace in Central America. Vol. 13, No. 10, March 1994.

19. Horn of Africa, Vot. 14, No.1, April 1994

20. The Russian Federation. Vol. 14, No.2, May 1994.

21. The Former Yugoslavia. Vol. 14. No.3, June/July 1994.

22. GenerallssuellRB and Rebuilding Trust/Tamil Immigrants in Canada, Vol. 14, No. 4. Aug./Sept. 1994.

23. Rwandan Crisis, Vol. 14, No.5. October 1994.

24. Refugee Resettlement in Israel, Vol. 14, No.6, Nov. 1994.

25. Refugee Women-Part 1: Issues. Vol. 14, No.7. Dee. 1994.

26. Refugee Women-Part 2: Case Studies. Vol. 14. No.8, Jan. 1995.

27. The Safe Third Country Concept, Vol. 14, No.9, February 1995.

28. Special Issue on Chcchnya, Vol. 14, No. 10, March 1995.

29. Reformulation oflnternational Refugee Law, Vol. 15. No.1, 1996

30. Environment. Dewlopment and Refugees, Vol. 15, No.2, 1996.

31. International Intervention in Refugee Crises, Vol. 15, No.3, 1996

32. Early Warning on Humanitarian Crises, VoL 15. No.4, 1996.

33. Child Refugees. Vot. 15, No.5. 1996.

34. Global Settlement Services, Vol. 15, No.6, 1997.

35. Early Warning and Early Response, Vol. 16, No.1, May 1997.

36. Uprooting and Consequences, Vol. 16, No.2, June 1997.

37. Dewlopment-induccd Displacement, Vol. 16, No.3. August 1997.

38. Refugee and Immigrant Women: An International Pet\$peetive, Vol. 16, No.4,

October 1997.

39. Working with Refugees and Internally Displaced Persons, Vol. 16, No.5.

November 1997.

40. Conflict, Population Displacement. and Conflict Resolution, Vol. 16, No.6,

December 1997.

Single copy: Vol 12. 13 \& $14-\$ 6.50$; Vol 15. 16.17-\$10. 10 percent discount on 3-9 issues (copies); 20 percent discount on 10 issues (copies) or more. Special discounts are available for stUdents and exclusively volunteer-run NGOs. P.O. accepted.

Please send your orders to:

Centre for Refugee Studies, York University

Suite 333, York Lanes, 4700 Keele Street

Toronto. Ontario. Canada M3J IP3

Fax: (416) 736-5837 Eroail: refuge@yorku.Ol. mswinder@yorku.Ol 


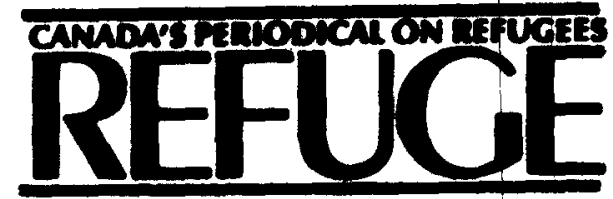

Refuge

Centre for Refugee Studico Suite 322, York Lanes

York Univenity

4700 Keele Street, Toronto

Ontario, Canada M3J 1P3

Phone: (416) 736-5663

Fax: (416) 736-5837

Email: refugeoyorku.ca

\section{ALL FOFPAPERS}

CALL PORPAPERS 